\title{
MARRIAGE DOT EU: THE EFFECT OF INTERNET USAGE ON MARRIAGE HAZARD
}

Mário Vozár
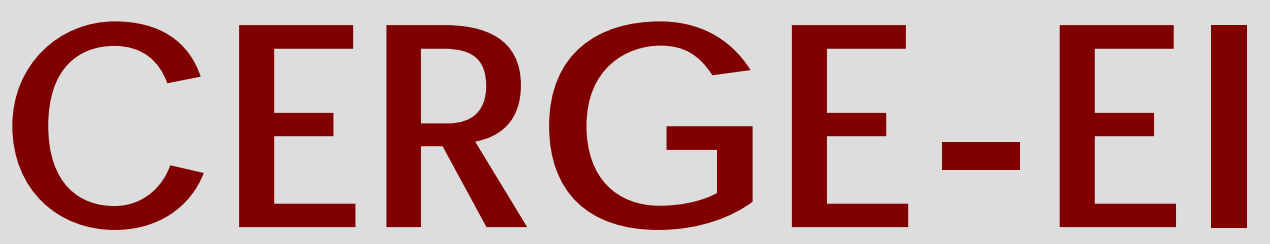

Cha rles University CenterforEconomic Research and Graduate Education Academy of Sciences of the Czech Republic Ec onomic Institute 


\title{
Working Paper Series 444 (ISSN 1211-3298)
}

\section{Marriage Dot EU: The Effect of Internet Usage on Marriage Hazard}

\author{
Mário Vozár
}

CERGE-EI

Prague, August 2011

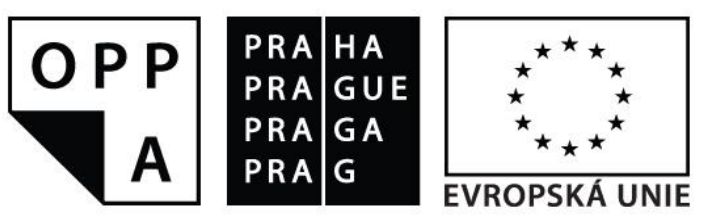

EVROPSKÝ SOCIÁLNÍ FOND

PRAHA \& EU: INVESTUJEME DO VAŠŚ BUDOUCNOSTI 
ISBN 978-80-7343-247-8 (Univerzita Karlova. Centrum pro ekonomický výzkum a doktorské studium)

ISBN 978-80-7344-239-2 (Národohospodářský ústav AV ČR, v.v.i.) 


\title{
Marriage Dot EU: \\ The Effect of Internet Usage on Marriage Hazard
}

\author{
Mário Vozár* \\ CERGE-EI ${ }^{\dagger}$
}

August 2011

\begin{abstract}
The rapid growth of internet usage over the last two decades has been influencing many aspects of our life and most noticeably the ways in which people communicate with each other. Therefore, it is appropriate to ask whether the growth of internet usage influences individuals' marital decisions in modern society. In my study, I concentrate on the effect of the growing internet usage on the gender and age-specific marriage hazard rate for the first time marriages in Europe. The panel data analysis reveals a negative impact of internet usage on male's as well as female's marriage hazard rate for those in their twenties.
\end{abstract}

\begin{abstract}
Abstrakt
Rýchly rast používania internetu v posledných dvoch desat’ročiach ovplyvňuje mnoho aspektov každodenného života. Dá sa povedat', že najvýraznejšie internet zasahuje práve do spôsobu, akým l'udia medzi sebou komunikujú. Preto je namieste pýtat' sa, nakol'ko rast internetu vplýva na najdôležitejší výsledok medzil’udskej komunikácie, a to rozhodnutie o vstupe do manželstva. V tejto štúdii sa sústredím na vplyv rastúceho používania internetu na načasovanie tohoto rozhodnutia. Panelová analýza ukázala, že rozšírenie internetu je do istej miery zodpovedné za predlžovanie priemerného veku vstupu do prvého manželstva, a to ako u mužov tak i u žien. Tento efekt sa však prejavuje iba do veku 27 rokov pre mužov a 26 rokov pre ženy.
\end{abstract}

Keywords: Marriage Market, Divorce, Internet

JEL classification: J12, L8

I would like to thank to Peter Katuščák for valuable comments and suggestions, Juraj Stančík for helping me to obtain the data and to Pavla Nikolovová for her great help with the text editing. All remaining errors are mine.

*Email: mario.vozar@cerge-ei.cz

${ }^{\dagger}$ Center for Economic Research and Graduate Education--Economics Institute, a joint workplace of Charles University in Prague and the Academy of Sciences of the Czech Republic. Address: CERGE-EI, P.O. Box 882, Politických vězňů 7, Prague 1, 111 21, Czech Republic 


\section{Introduction}

Over the last two decades, the internet has become truly widespread, and there is no doubt that these new means of communication influenced and profoundly changed many substantial aspects of our lives. Email usage became standard, online dating sites multiplied, social networks' popularity has been spectacularly growing, all giving evidence of the noteworthy role that online communication plays in our lives nowadays and of the very different opportunities we have now as compared to the situation some twenty years ago.

It is probably the young people that are naturally the most apt to exploit fully these opportunities, and there are several ways in which the means of online communication may make their life both easier and richer as compared to the generation of their parents. One particular situation might be the search for a life partner, who now does not have to be sought for only in the real world, but who might be encountered on the internet first. There are enough examples of happy couples that met for the first time on a social network, a discussion forum or other web platform, or who found each other directly through the services of an online dating site. Considering these successfully formed partnerships, it is appropriate to ask whether the growth of internet usage influences individuals' marital decisions in modern society, which is the research question of my paper.

I contribute thus to a growing number of studies exploring this compelling topic, both from a sociological and an economic point of view. My study is positioned within the economic stream of literature, and there I present an econometric approach that allows me to estimate the effect of an increasing internet usage on individuals' marital decisions. I run my estimation under a fixed effect model with a gender and age-specific marriage hazard rate at first marriage as the dependent variable, using within country variation over the period 1990 to 2008. Extending the paper, I use the obtained results to shed some light on the effect of the increasing internet usage on the divorce rate.

There are certainly many aspects of marriage that internet usage can influence, 
but I decided to concentrate mostly on the beginning of the marital process. I am particularly interested to see if the reduction of search costs, given by the fact that through the internet, more potential partners can be reached in a significantly shorter time, leads people to marry sooner or later. Both outcomes can be supported by the marriage market theory since reduced search costs allow people to meet acceptable partners sooner, but they also make it less riskier to postpone the decision and to wait for even more suitable candidates. The results of my analysis confirm rather the latter hypothesis.

The paper is organized as follows. In Section 2, I provide a review of literature relevant to my research, Section 3 concentrates on the specification of my econometric model, and Section 4 contains a detailed description of the data I am using for my analysis. In Section 5, I summarize the results of the baseline model and provide further theoretical explanations to support them. In section 6, I present two extensions that further improve my analysis: cohort specific cumulative internet exposure and the analysis of the effect of internet usage on the divorce rate.

\section{Literature review}

The propagation of the internet and the consequent enrichment of the means of communication bring one of the biggest changes ever to the social interaction of people. Therefore, it is no surprise that a growing number of academic studies is aiming to describe and understand this phenomenon, presenting it under its various aspects and from different points of view.

One of the many facets of this issue is the impact of the increasing internet usage on the interaction between potential marital partners, at the beginning as well as in the course of their relationship; thus, we can find many papers, both in sociological and economic fields, that concentrate on the effect of the internet on the market for romantic partners.

The first issue that has to be addressed here is the impact of the internet on 
social interaction in general. Putnam (2000) argues that the expansion of modern communication technologies, like TV consumption or internet usage, results in the decline of social capital. In other words, the author claims that the use of modern technologies crowds out social participation and hence, put into the marriage market perspective, one could argue that the decline in social participation would result in fewer marriages over time. However, the empirical study by Bauernschuster, Falck, and Woessmann (2011) found no evidence that use of the internet reduces social capital. On the contrary, the authors found a positive effect when the internet is used to purchase or reserve tickets for culture events. These findings thus support the view of the internet as an influential communication tool with a potential to influence our personal lives and our romantic relationships.

Various studies in sociology (Merkle and Richardson, 2000; Underwood and Findlay, 2004; Young, Griffin-Shelley, Cooper, O’Mara, and Buchanan, 2000) compare what are called computer mediated relationships with face-to-face relationships. All authors agree that as the access to the internet service increases, the number of computer mediated relationships grows as well. For what concerns the nature of these "online" relationships, in their study conducted on a sample of 75 adults, Underwood and Findlay (2004) stress especially the intimacy and the importance of the relationship perceived by the subjects of the study. Similar to these authors, Merkle and Richardson (2000) conclude that individuals often describe their online relationships as intimate and as authentic as face-to-face relationships. Further parallels between online and face-to-face relationships were confirmed by Hitsch, Hortacsu, and Ariely (2010), who compared the distributions of partners' characteristics under both arrangements and found no difference. Hence, the computer-mediated relationships can be considered as substitutes for face-to-face relationships, and moreover, as Merkle and Richardson (2000) point out, there is an increasing trend to use the internet as a medium for finding a romantic partner. This is why both researchers and policy makers should acknowledge and prepare for the increasing role of the internet in the personal lives of individuals. 
While sociologists concentrate mainly on the individuals' perception of online relationships and their comparison with face-to-face relationships to find what the effect of the internet is on the marriage market, economists regard the growing internet access mainly as a shock to the matching function. Stevenson and Wolfers (2007) see the internet as a shock expanding the pool of potential partners on the one hand but increasing the anonymity on the other hand. While the first effect may be of great importance for those looking for a partner, and it may foster the number and the quality of created matches, the increased anonymity may encourage those engaging in infidelity and contribute to increased match separation. Indeed, as the authors point out, the data reveal that a significant number of online dating site users are currently married. The authors themselves acknowledge that the internet may have various effects on the marriage market, and that it is unclear whether the decline in the search costs would result in matches with higher quality and what the final effect on marriage and divorce rates would be.

The contradictory effects the internet may have on the marriage market are extensively summarized in Kendall (2010), whose hypotheses follow closely Becker (1973). Kendall tried to estimate the effect of internet usage on the divorce rate. He did not find its usage to have a significant effect here, but he discussed several reasons explaining the obtained results. While there is no doubt that the expansion of the internet lowers the search costs, it is not clear whether it reduces or increases the time people spend searching for their marital partner. As Becker (1973) argues in his seminal paper, the decline in the search costs should lead to longer searches and better quality of matches since it is more affordable to wait until a good enough match is found. On the other hand, Kendall claims that forward-looking individuals may enter even a potentially less satisfying marriage because they are unafraid of the negative effect of divorce since they believe that the chances of finding a good enough match later on are higher. This would result in individuals lowering their acceptance threshold and continuing to search for a better partner while matched.

The potential of the internet to transform the market for romantic partners is 
indisputably acknowledged by the majority of authors working in this field. However, these authors also agree that it may be too early to assess the definite result of this transformation. I share this point of view especially with respect to the effect of internet on the stability of matches: This stability is not only threatened by the broadened scope of outside options available to internet users, but it depends also on the quality of the match given at the time of its formation. If this quality is influenced by the usage of the internet, it means that the causes of a marital breakup and the breakup itself may be separated by a significant period of time. This is why we may not yet be able to evaluate all aspects of this complex issue.

However, this also shows why it is important to understand how the initial match formation is influenced by the growing usage of the internet, which is a question that has been somehow overlooked in the existing empirical literature. My paper aims to fill this gap.

\section{The Model}

My empirical work is inspired by the approach of Kendall (2010), who analyzed the effect of the internet on the divorce rate in the US. For reasons explained in the previous section, I explore rather the relationship between the internet and match formation, and I study the impact of the growing internet usage on the marriage hazard rate.

I suspect a priori the internet usage to have two opposite effects. This is because while Becker argues that the decline in the search costs caused by a growing internet usage should lead to longer searches and better quality matches, one can also come up with an alternative hypothesis. As it is cheaper and especially easier to search for a suitable match, especially young potential marital partners may become less afraid of the difficulties of finding a new partner when there is an unfortunate end of marriage by divorce. This may, on the contrary to Becker's prediction, lead to shorter searches and potentially a worse quality of matches. Taking into consid- 
eration both theories, one can argue that the effect of the internet may shift the marriage hazard rate both ways, upwards and downwards, and this shift may also depend on the age of those looking for a marital partner. My analysis should show in which direction the overall influence goes and how it depends on the potential partners' age.

To identify the effect of internet usage on match formation, I focus on gender and age-specific marriage hazard rate of those marrying for the first time. Since age-specific marriage hazard rates are independent, I estimate the effect of the growing internet usage on the marriage hazard rate for every age at first marriage independently. Thus, my basic specification, conditional on gender and age at first marriage is

$$
\begin{aligned}
& \ln \left(\text { marriage hazard }_{i, t}^{\text {age,gender }}\right)=\alpha \ln \left(\text { internet access }_{i, t}\right)+\beta X_{i, t}^{\text {age,gender }}+ \\
& +\gamma_{i}^{\text {age, gender }}+\mu_{t}^{\text {age,gender }}+\varepsilon_{i, t}^{\text {age,gender },}
\end{aligned}
$$

where $i$ is the country index, and $t$ is the time index. Further, $X_{i, t}$ denotes the vector of other controls, and $\gamma_{i}$ and $\mu_{t}$ denote country- and year- fixed effects, respectively. I use country fixed effects to control for potential cultural differences between countries that may influence both computer literacy and marriage patterns, and I add time fixed effects to remove a time trend, which I suspect drives many changes in modern society, and which I assume to be common to all countries.

Inspired by the work of Kendall (2010), I include among my controls the unemployment rate, the real GDP per capita, the income inequality and also in some specifications the share of tertiary educated in the population with all covariates used in logs. The unemployment rate and real GDP per capita should clearly have an impact on the marital decision, as was nicely demonstrated in the theoretical model of Bergstrom and Bagnoli (1993). The decision to control for the effect of income inequality is motivated by the study "A Nation Online" by the U.S. Department of Commerce (2002), who found that the Lorenz Curve measuring the inequality in internet usage at home against income has a similar shape as the traditional Lorenz Curve computed for income inequality. This suggests that dif- 
ferences between countries reflected by their Gini coefficients have the potential to explain the mechanism of internet usage as a tool for searching for a future spouse. Since I suspect also that this mechanism can directly depend on the level of inequality, I control for the interaction between the Gini coefficient and the internet usage as well. Finally, accounting for the effect of tertiary education in all specifications except one enables me to control especially for the generational shift in the delayed age at first marriage.

\section{Data Description}

I use the country level data for European countries over the years 1990 to 2008. To identify the effect of the growing internet usage on first time marriages, I construct my dependent variable; the gender and age-specific marriage hazard rates using data from the Eurostat New Cronos database available through the Eurostat homepage. For each country and each year, I have information on separate cohorts, mainly the number of people that were single (and never married before) as of the 1st of January, and also the number of people that married for the first time in the given year. I consider age at marriage from 20 to 49 years, and I compute the marriage hazard rates for each age at first marriage as the share of the number of first marriages and the number of singles. I construct these variables separately for men and for women, and so the corresponding formula can be written as

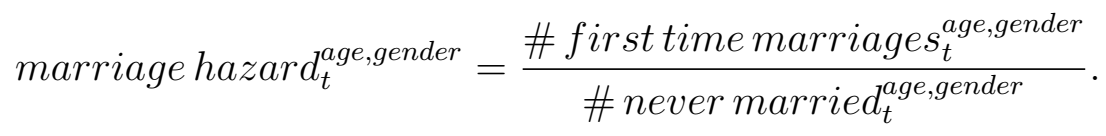

Due to constraints with data availability for the whole period of 1990 to 2008, the analysis relies on data from 21 European countries. Following Kalmijn (2007), these countries can be divided into four regions based on their marriage patterns: Western, Southern, Northern, and Central-Eastern Europe as can be found in Table 1.

At this point, it is important to address the question of different marriage pat- 
Table 1: List of Countries

\begin{tabular}{llll}
\hline \hline Western & Northern & Southern & Central-Eastern \\
\hline Belgium & Denmark & Italy & Bulgaria \\
Germany & Finland & & Croatia \\
Luxembourg & Norway & Czech Republic \\
Netherlands & Sweden & Hungary \\
Switzerland & & Latvia \\
United Kingdom & & Lithuania \\
& & Poland \\
& & Romania \\
& & Slovakia \\
& & Slovenia \\
\hline \hline
\end{tabular}

terns across European countries. Kalmijn (2007) claims that there are in some aspects significant differences between marriage patterns across European countries. He finds that age at first marriage, which is closely related to the age-specific marriage hazard rate, is the biggest in Northern Europe with average age at first marriage being equal almost to 28 years. On the contrary, it is the smallest in Central-Eastern Europe, averaging at only slightly more than 22 years. This difference is clear in Figures 1 and 2 in which I plot age-specific marriage hazard rates for representative countries from the four regions first in 1995 and then in 2007, and it justifies my decision to include in my model country fixed effects. Moreover, the two figures show that between year 1995 and 2007 there was a significant shift in marriage hazard rates: in all countries, males as well as females postponed their decision to enter marriage. More importantly, it should be noticed in the two figures that the character of differences between countries seems to be the same before and after the shift. This allows me to assume that the time trend is common for all countries in my sample, and so, that country and simple time fixed effects are sufficient to capture the general dynamic of the process ${ }^{1}$.

\footnotetext{
${ }^{1}$ Note that this assumption is further verified by a robustness check presented in the results section.
} 

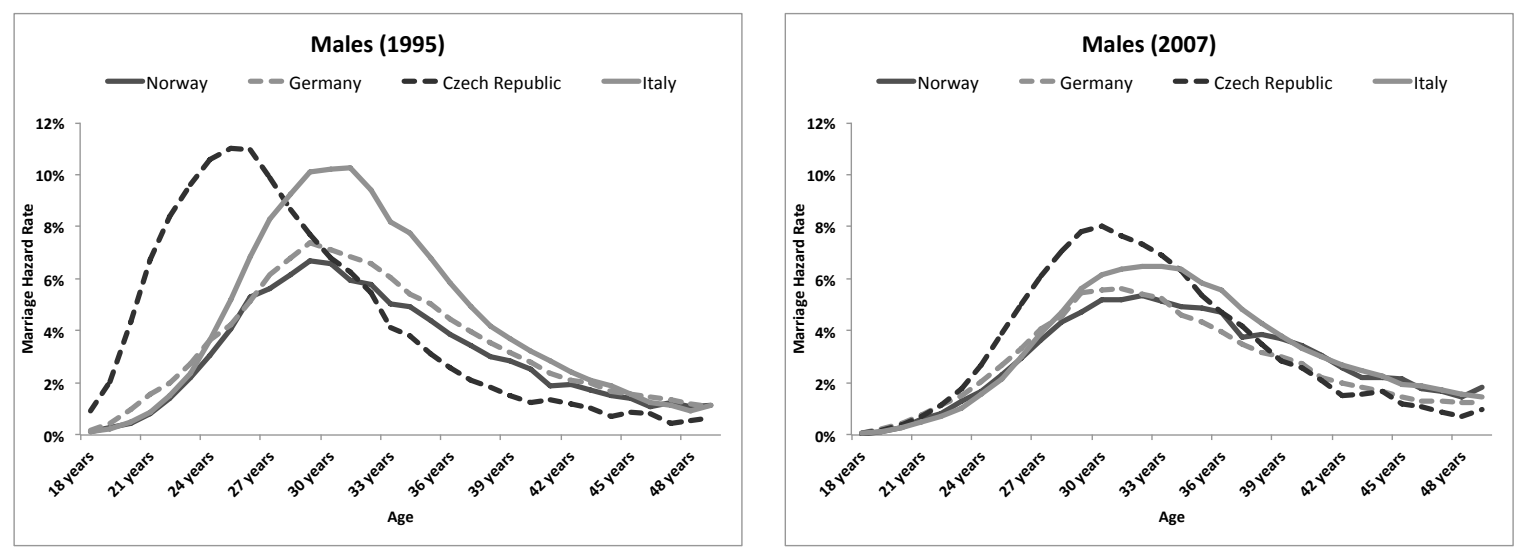

Figure 1: Hazard Functions for First-time Marriages (Males)
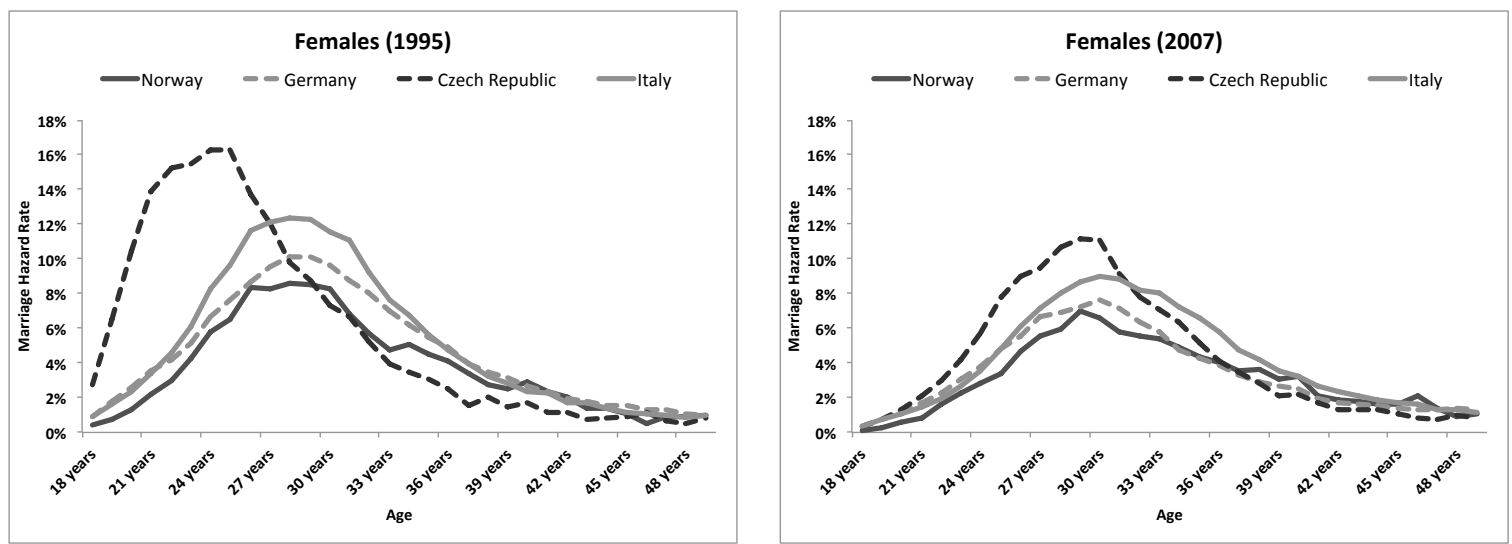

Figure 2: Hazard Functions for First-time Marriages (Females)

For what concerns the internet usage, which is the variable of interest in my model, I obtain it from the macro level ICT Statistics Database constructed by the United Nations agency International Telecommunication Union. Since it is impossible to identify whether the internet is used particularly as a tool for looking for a romantic partner or not, I have to rely on a variable describing the percentage of internet users for a given country and year accessible through the UN database. However, I am positive that the assumption of a proportional relationship between the general usage of the internet and usage of the internet for romantic purposes is reasonable enough.

The list of control variables that completes the constructed dataset consists of male and female unemployment rates, real GDP per capita, the Gini coefficient index, and the share of population possessing tertiary education conditional on age. All these variables with the exception of the Gini coefficient index are also taken from 
the Eurostat New Cronos database available through the Eurostat homepage. The Gini coefficient index is a compound of the data available at Eurostat with a unique dataset constructed by the United Nations University, World Institute for Development Economics Research, which unifies data about income inequality from a vast number of studies and surveys (available at http://www.wider.unu.edu/research). The Gini coefficient for the analyzed countries can be found in Table 2 .

The evolution of the percentage of internet users is presented in Table 3. As expected, in all countries internet usage strictly grows from almost zero at the beginning of the 90 s to in some cases almost $90 \%$ at the end of the last decade. However, even at the end of the analyzed time period, the internet penetration differs significantly between countries, with the percentage of internet users in Scandinavian countries representing almost double the percentage of internet users in Southern Europe or in post-communist countries.

Summary statistics for the remaining explanatory variables can be found in Table 4 with mean and standard deviation computed over the analyzed time period.

\section{Results}

In this section, I discuss the estimation results obtained from the empirical model defined in section 3. I present two main specifications, referred to as Model 1 and Model 2. As a robustness check, I also use an additional specification labeled Model 3. The three specifications differ mostly in ways in which they address concerns about the estimated relationship between the internet usage and the marriage hazard rate being caused only by long-term trends. All models are estimated separately for the two genders and for all cohorts starting with age 20 and ending with age 49. Standard errors are clustered on country level in all cases.

The first specification, presented as Model 1, includes the percentage of internet users, a gender-specific unemployment rate, real GDP per capita, the Gini coefficient, and the interaction between the percentage of internet users and the Gini 
coefficient as explanatory variables for the marriage hazard rate. Time and country fixed effects are included as well. The results are presented in Tables 6 and 7 for males and females respectively. We observe that the internet usage has negative impact on the marriage hazard rate for younger cohorts, whereas some positive impact for older cohorts can be found in the case of males. The signs of the other controls are as predicted by the marriage market theory. The interaction term between internet usage and the Gini coefficient is of the opposite sign as the coefficient for internet usage only, signaling that the effect of the internet is stronger in countries with lower inequality. This can be explained when we take into account the finding of Fuchs (2009), who claims that in countries with higher inequality, the actual usage of the internet is less intensive even if the percentage of users might be relatively high. The author explains that the internet, as opposed to other technologies, requires not only an initial investment but also has recurring charges, which make it more difficult to benefit fully from internet services for people from the lower tail of the income distribution.

In the second specification, presented as Model 2, I add to the controls the percentage of the tertiary educated in a given gender and age group that acts as a proxy for the generational change, which may influence marital behavior in a more complex way than the common time trend represented by time fixed effects (which are still used in this model, as well as the country fixed effects). The results are presented in Tables 8 and 9 for males and females respectively. They are very similar to those of Model 1 for what concerns the coefficients of internet usage and other controls. The education coefficient is negative, confirming the hypothesis that more educated people tend to postpone marriage.

The third specification, presented as Model 3, serves as a robustness check. In terms of control variables, it is the same as Model 2 only it does not include country and time fixed effects as such, but it accounts for the country-specific time trends. It is important to stress that country-specific trends in this specification capture most of the variation and thus leave very little explanatory power to the covariates. 
Despite this fact, the results presented in Tables 10 and 11 suggest that the effect of the internet goes in the same direction as in Model 1 and Model 2, only the standard errors are too large for the coefficients to remain significant, with the exception of a few age categories for males. Nonetheless, we have to be aware here that this is probably because only with so many estimated effects, we demand too much of the data we have at our disposal.

It has to be noted that aside from the three mentioned models, I tried even a nonlinear specification for internet usage with not only the interaction term between the internet and the Gini coefficient but also with higher orders of these variables. This did not induce any major changes to the results, and so finally, I account only for the linear effect of internet usage and for the interaction term.

Because this interaction term is included in my model and significant, it is clear that the influence of internet usage on the marriage hazard rate is non-linear and cannot be expressed only by the coefficient corresponding to the internet usage. This is why I show rather the marginal effect of internet usage computed at the mean Gini (which equals 29.37) in Table 5. The results are presented for all three specifications and confirm the similarity of Model 1 and Model 2 as well as the loss of significance in Model 3.

I will consider Model 2 as my main specification for further discussion and more detailed presentation of the results. I believe it is parsimonious enough so that the explanatory power of my variable of interest is not diluted as in Model 3, but that it controls better than Model 1 for the generational change, which might possibly drive both internet usage and marriage patterns. Hence, Model 2 probably offers the best identification of the effect for which I am looking.

In Figure 3, I graphically represent the marginal effects of internet usage estimated in Model 2 for both males and females with a 95\% confidence interval included. We can see there that the internet usage or rather the decrease in search costs caused by the increasing use of the internet has a negative effect on the marriage hazard rate for certain age categories. This negative effect is largest at age 21 
for both males and females and slowly decreases to zero in subsequent years. The effect of internet usage is not distinguishable from zero at the $95 \%$ confidence level for the age groups of 28 and older in the case of males and the age groups of 26 and older in the case of females. When comparing the two genders, we can say that the effect on the marriage hazard rate of males is only slightly larger in absolute value, which supports the claim that there is not much of a gender gap in the way the internet is used for social communication.
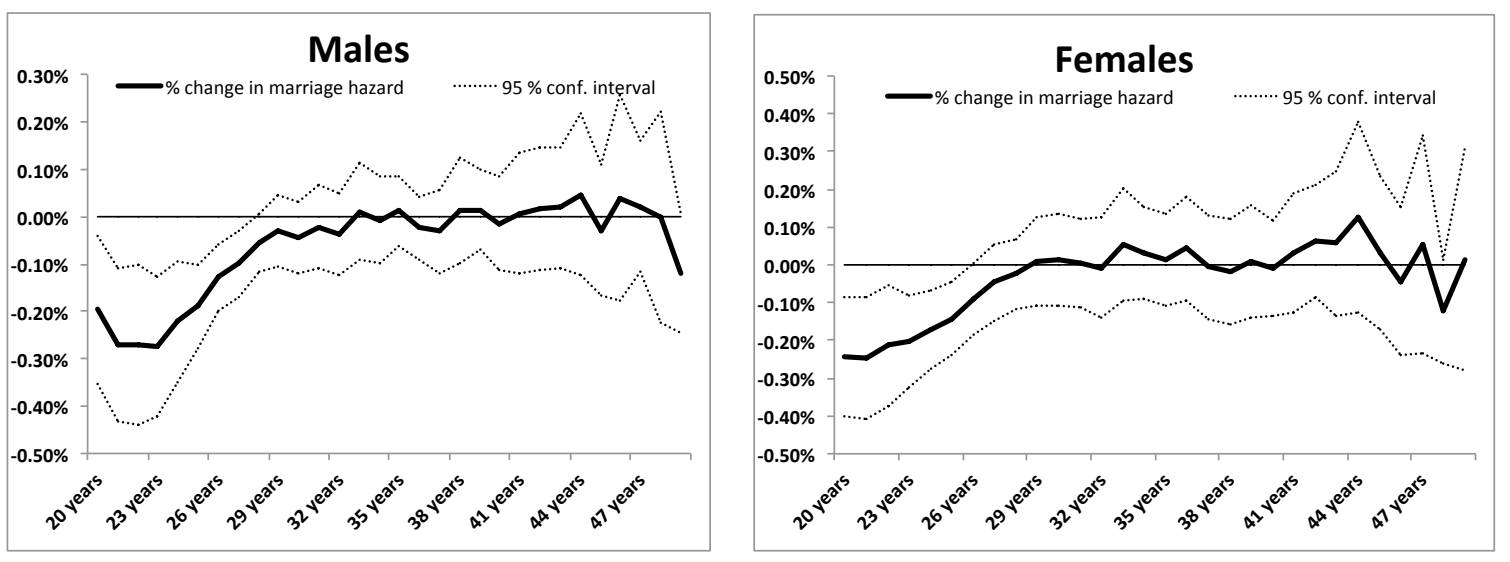

Figure 3: The percentage change in marriage hazard caused by an increase in internet usage by 1 percent

To further illustrate the overall effect of the internet on the marriage hazard rate over the analyzed time period, I present Figure 4. First, I construct the baseline marriage hazard curve as the average marriage hazard rate in year 1995 when the internet usage started to grow (solid black line). Then, I construct the same for the year 2008 (solid grey line). Finally, I recompute the marriage hazard curve as it would be in 1995, but with the levels of internet usage as in 2008 (dashed black line). The comparison of these curves helps me to contrast the overall shift in the marriage hazard rate and the part of the shift that we can attribute solely to internet usage growth.

It is clear from Figure 4 that the internet usage contributes only to a fraction of the overall shift towards a higher age at first marriage. Moreover, this figure helps to address potential concerns about the identified effect of the internet usage being driven mostly by the overall shift in the marriage hazard rate over years. If it was 

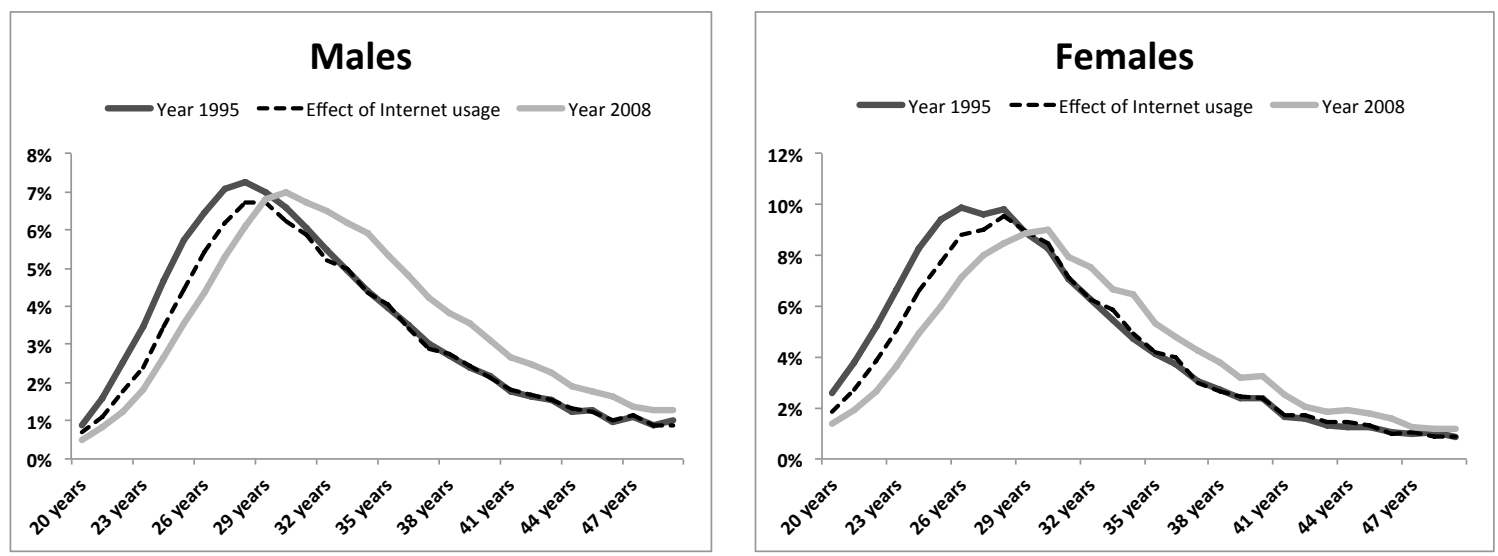

Figure 4: The effect of internet usage on the marriage hazard rate between the years 1995 and 2008

so, the effect of the internet would simply shift the whole curve for all age cohorts because this is exactly how the overall pattern changed between the years 1995 and 2008. The marriage hazard rate as such decreases until age 30 and increases in subsequent years, whereas the effect of internet usage was identified to be significant only until age 27 in the case of males and 25 in the case of females. This means that the modification of the curve given by the growth of internet usage does not simply mirror the overall shift, but that it really captures the proper mechanism of the studied effect.

This allows me to believe that internet usage has an effect on marital decisions for those in their twenties. The negative sign of the effect suggests that the decrease in the search costs caused by the increasing role of the internet in personal lives supports Becker's claim of consequently longer searches and eventually even better quality of matches.

\section{$6 \quad$ Extensions}

Although the analysis presented so far answers basically the research question of my paper, there are several ways how it can be extended and complemented by regarding the issue from a different perspective. In this section, I will provide two such perspectives that will shed new light on the studied issue. First, I slightly 
transform my treatment variable (internet penetration) in order to take into account that different cohorts may be exposed to the internet in different ways, and second, I complement my analysis of marriage patterns by briefly also discussing the issue of divorce rate.

\subsection{With-in cohort estimation}

So far, I estimated my model separately for age groups and with a time fixed effect. Since the age groups are separated, the time fixed effects also differentiate the distinct cohorts, and so I control for the differences in marriage patterns between people with different years of birth. However, my specification does not take into account that the overall exposure to internet penetration varies across cohorts: Individuals in different cohorts have been exposed differently to the internet phenomenon throughout their life. To address this issue, I repeat the analysis on the cohort level using an approach inspired by Donohue and Levitt (2001); I use the cumulative internet usage computed since age 20 as my explanatory variable of interest. The altered specification, conditional on gender and age at first marriage is

$$
\begin{aligned}
& \ln \left(\text { marriage hazard }_{i, \text { cohort }}^{\text {age,gender }}\right)=\alpha \ln \left(\text { cum.internet access }_{i, \text { cohort }}\right)+\beta X_{i, \text { cohort }}^{\text {age,gender }}+ \\
& +\gamma_{i}^{\text {age,gender }}+\mu_{\text {cohort }}^{\text {age,gender }}+\varepsilon_{i, \text { cohort }}^{\text {age,gender }},
\end{aligned}
$$

where $i$ is the country index, and cohort is the cohort index. Further, $X_{i, \text { cohort }}$ denotes the vector of other controls, and $\gamma_{i}$ and $\mu_{\text {cohort }}$, state- and cohort- fixed effects, respectively. Again, I use country fixed effects to control for the potential cultural differences between countries that may influence both computer literacy and marriage patterns, and I add cohort fixed effects to remove a time trend, which I suspect drives many changes in modern society and which I assume to be common to all countries. These fixed effects operate in the same way as those in my previous specification.

Based on my conclusions from the previous section, I estimate the model using only the second specification. Thus, I control for the percentage of the tertiary educated in a given gender and age group to proxy for the generational change. 
Moreover, I control for common time trends represented by cohort fixed effects as well as the country fixed effects. The remaining explanatory variables remain the same as in the previous section (real GDP per capita, the unemployment level, the Gini index, and the interaction between the Gini index and cumulative internet usage. I present the results in Tables 12 and 13 for males and females, respectively. The estimation results are both qualitatively and quantitatively similar to those of Model 2 for what concerns the coefficients of internet usage and other controls.

Because of the interaction term between cumulative internet usage and the Gini index, the influence of internet usage on the marriage hazard rate is nonlinear and cannot be expressed only by the coefficient corresponding to the internet usage. This is why I again present also the marginal effect of internet usage computed at the mean Gini (which equals 29.37) in Table 14 . Again, the results are comparable to those obtained using the Model 2 specification in the previous section. I graphically represent marginal effects of internet usage for both males and females with a $95 \%$ confidence interval included in Figure 5. It is clear that the corresponding graphs, representing the estimating effects, are almost the same in size and structure to those presented in Figure 3.
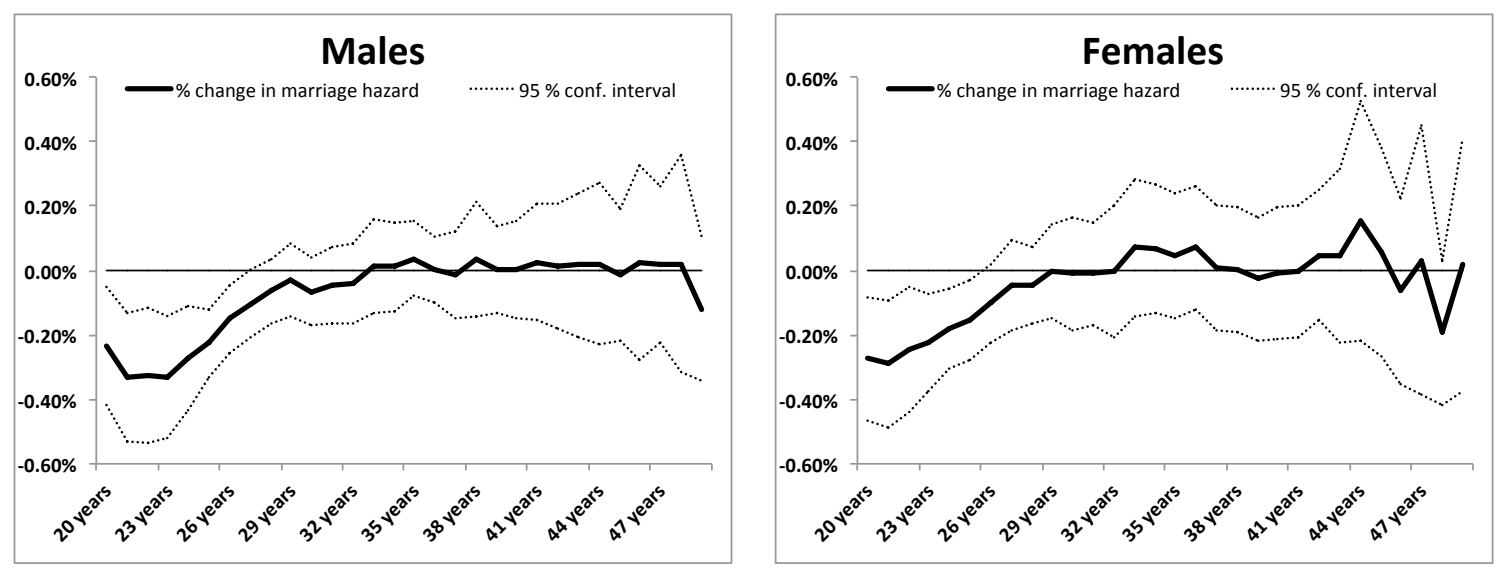

Figure 5: The percentage change in marriage hazard caused by an increase in internet usage by 1 percent

The results presented in this section strengthen my belief that internet usage has an effect on marital decisions for those in their early twenties. To reiterate my previous claim, the negative sign of this effect suggests that the decrease in the 
search costs caused by an increasing role of the internet in personal lives supports Becker's claim of consequently longer searches and potentially even better quality of matches.

\subsection{Divorce rate}

The main aim of this paper is to answer how the decrease in search costs caused by an increasing role of the internet in personal lives influences marriage hazard. The results support Becker's theory that suggests longer searches and potentially a better quality in realized marriages. In addition, this result gives me an opportunity to shed some light on the effect of the internet on the divorce rate. As I already argued, the estimated effect of internet usage on the divorce rate is, in the long run, a composition of direct as well as indirect effects. Thus, it makes it very difficult to make any inference about the sign and size of the direct effect I am interested in. This issue was discussed by Kendall (2010), who estimated the effect of internet penetration on the divorce rate. One of the potential reasons for Kendall's results is the fact that the direct and indirect effects influence the divorce rate in the opposite directions and thus canceled out.

The analysis I performed with respect to the effect of internet usage on the marriage hazard rate allows me to assess the direction of the indirect effect of internet usage on the divorce rate. If Becker's theory is to be believed, a longer search time which I confirmed should eventually lead to a better quality of matches and thus result in a decrease in the divorce rate. However, before making any inference about the direct effect of internet usage on the divorce rate, the overall effect has to be estimated. Using the Eurostat data on divorce rates, I estimate the overall effect using the same set of explanatory and control variables as in the Model 2 specification.

The results are presented in Tables 15 and 16. The marginal effect of internet usage on the divorce rate is found to be significant at the $1 \%$ significance level and most importantly has a positive sign. I believe this estimated effect is composed 
of the direct and indirect effects. As I already argued, findings presented in this paper, complemented by Becker's theory suggesting improvements in match quality as a result of longer searches, imply a negative sign of the indirect effect of internet usage on the divorce rate. While I found the overall effect to have a positive sign, the direct effect of internet usage on divorce rates has to be positive as well. In other words, a decrease in the search costs caused by the increasing role of the internet in personal lives has to have a negative impact on marriage stability. The intuition behind this result may lie in the increased prospects the internet brings to those looking for a new partner, for example in the form of specialized dating web sites or forums.

\section{Conclusion}

In this paper, I contributed to the still limited but already growing pool of literature, which seeks to describe and understand the effects of internet usage on the marriage market. I concentrated on marriage formation since I believe that it is important to first understand how the internet affects this particular aspect of the marriage market, which has a crucial impact on the overall quality and stability of the resulting matches. Only with this knowledge will we be able to fully assess the effect of the internet usage on topics like the divorce rate and others in the future.

I conducted my econometric analysis on a panel of 21 European countries over the time period 1990 to 2008 with the gender and age-specific marriage hazard rate as the dependent variable using both with-in and between cohort approaches. The data allowed me to estimate the impact of internet usage specific for every gender and age group. I found a negative effect for internet usage on the marriage hazard rate for males as well as for females in their early twenties. This effect is only slightly stronger for males, but it remains significant until a higher age than in the case of females.

I discussed why the change in marital behavior caused by a decline of search 
costs attributed to internet usage may have different explanations for individuals of different ages, and I showed that my results rather confirmed the validity of Becker's theory of longer search times as opposed to other conjectures debated in the literature. Further, following Becker's theory, I was able to estimate the sign of the direct effect of internet usage on the divorce rate, which I find to have a positive sign. This suggests that the increased prospects from using the internet for those looking for a new partner have a negative impact on marriage stability.

To conclude, my analysis showed that growing internet usage has the potential to change the marital behavior of individuals. Even though right now it may be still too early to assess the long-term impact of these changes, future research may bring interesting insight into how they reshape whole marital patterns and especially what the consequences for marital stability in the long run would be. 


\section{References}

Bauernschuster, S., Falck, O., and Woessmann, L. (2011). Surfing Alone? The Internet and Social Capital: Evidence from an Unforeseeable Technological Mistake. SSRN eLibrary.

Becker, G. S. (1973). A theory of marriage: Part 1. Journal of Political Economy, 81(4):813-46.

Bergstrom, T. C. and Bagnoli, M. (1993). Courtship as a waiting game. Journal of Political Economy, 101(1):185-202.

Donohue, J. J. and Levitt, S. D. (2001). The impact of legalized abortion on crime*. Quarterly Journal of Economics, 116(2):379-420.

Fuchs, C. (2009). The role of income inequality in a multivariate cross-national analysis of the digital divide. Social Science Computer Review, 27:41-58.

Hitsch, G. J., Hortacsu, A., and Ariely, D. (2010). Matching and sorting in online dating. The American Economic Review, 100(1):130-163.

Kalmijn, M. (2007). Explaining cross-national differences in marriage, cohabitation, and divorce in europe, 1990-2000. Population Studies, 61(3):243-263.

Kendall, T. (2010). The relationship between internet access and divorce rate. Journal of Family and Economic Issues, pages 1-12.

Merkle, E. R. and Richardson, R. A. (2000). Digital dating and virtual relating: Conceptualizing computer mediated romantic relationships. Family Relations, 49(2):187-192.

Putnam, R. D. (2000). Bowling Alone: The Collapse and Revival of American Community. Simon \& Schuster.

Stevenson, B. and Wolfers, J. (2007). Marriage and divorce: Changes and their driving forces. Journal of Economic Perspectives, 21(2):27-52. 
Underwood, H. and Findlay, B. (2004). Internet relationships and their impact on primary relationships. Behavior Change, 21(2):127-140.

U.S. Department of Commerce (2002). A nation online: How americans are expanding their use of the internet. Available at http://www.ntia.doc.gov/ntiahome/dn/anationonline2.pdf.

Young, K. S., Griffin-Shelley, E., Cooper, A., O’Mara, J., and Buchanan, J. (2000). Online infidelity: A new dimension in couple relationships with implications for evaluation and treatment. Sexual Addiction \& Compulsivity: The Journal of Treatment $\&$ Prevention, 7(1):59-74. 


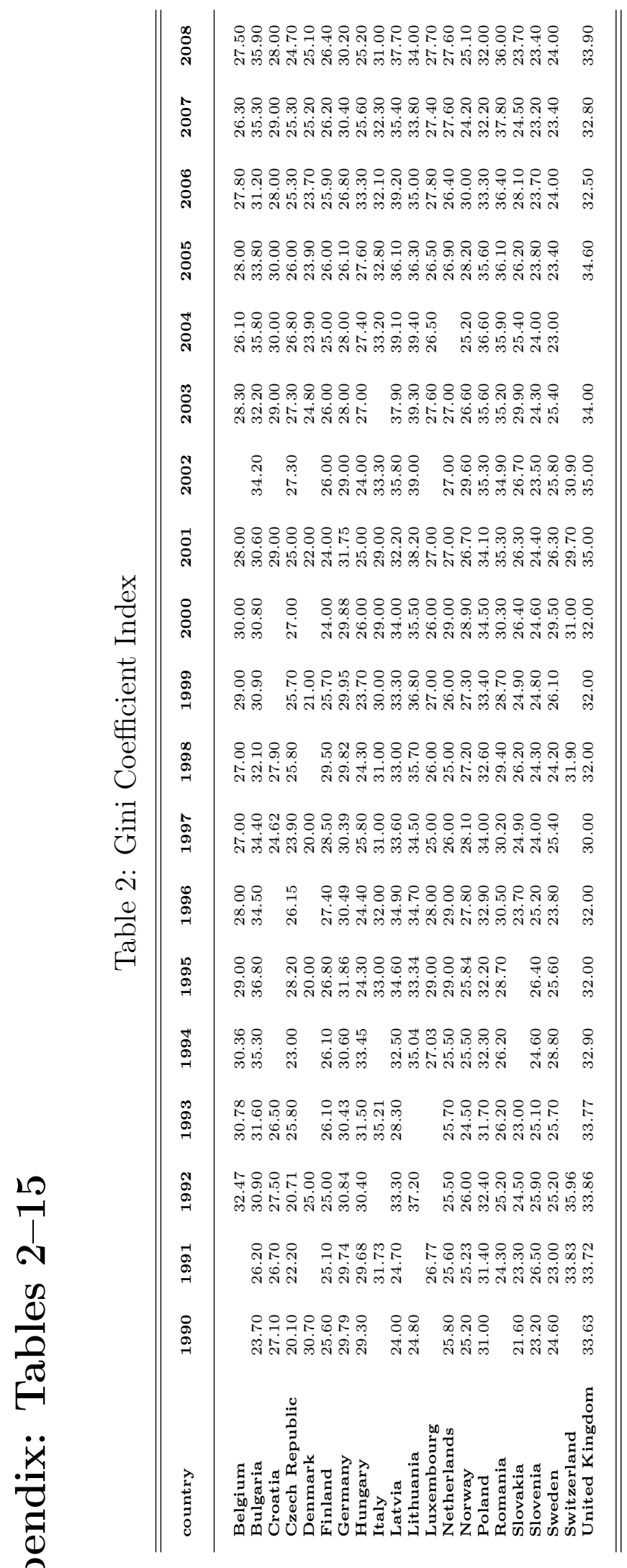

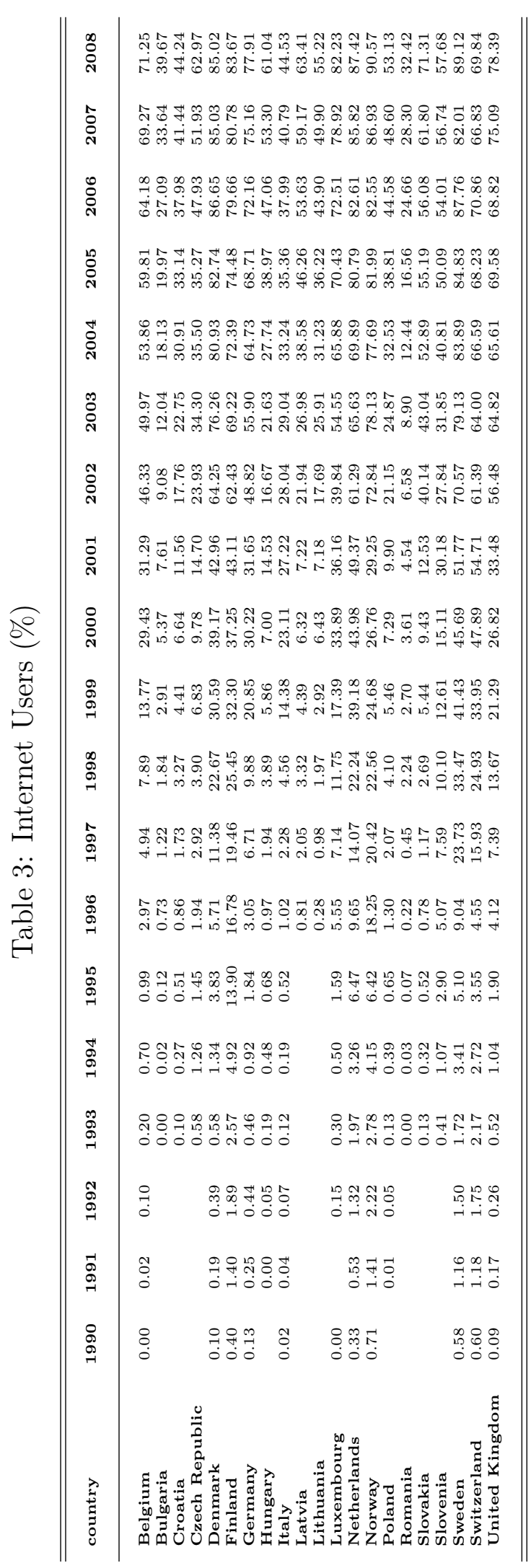




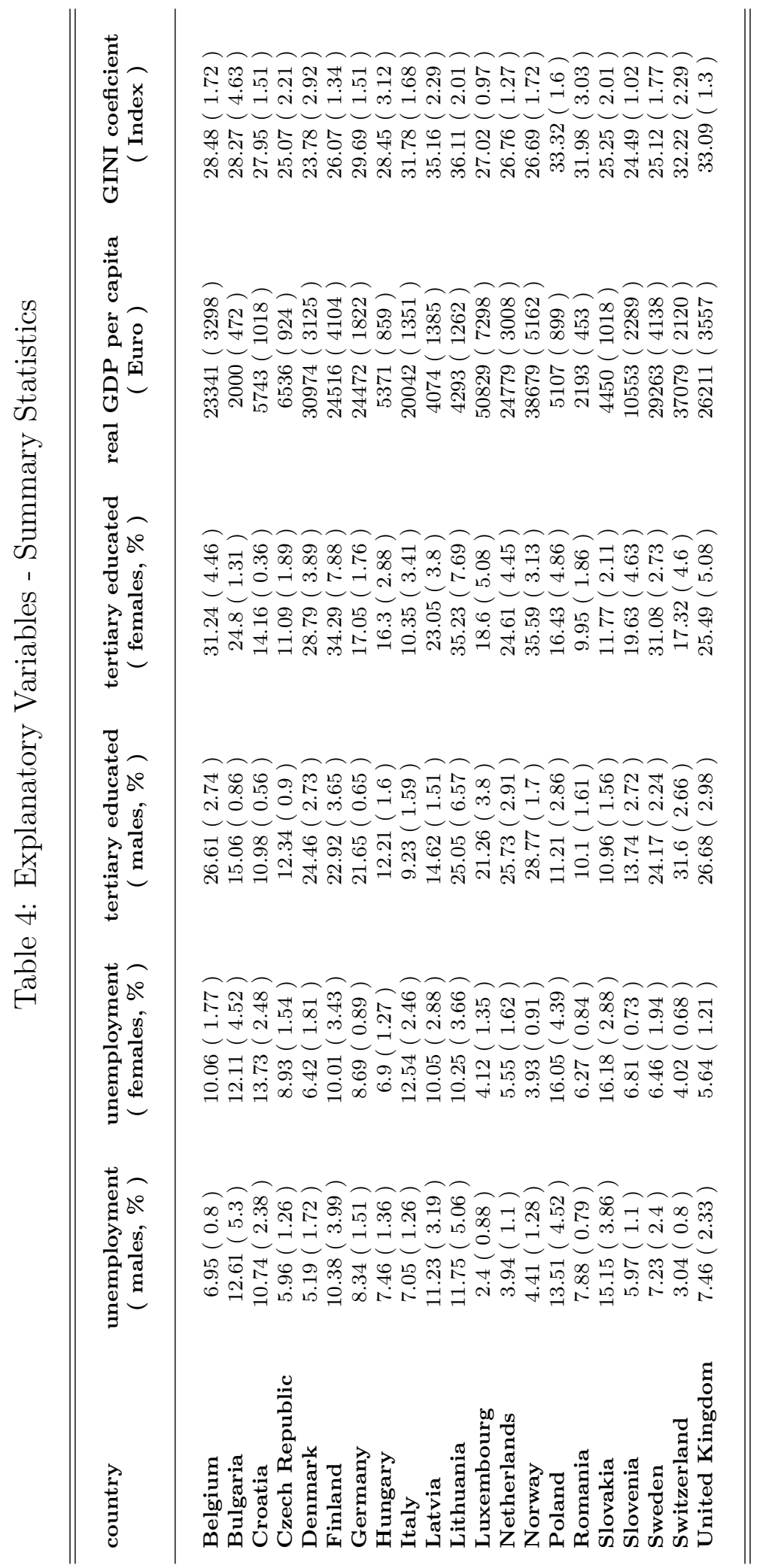




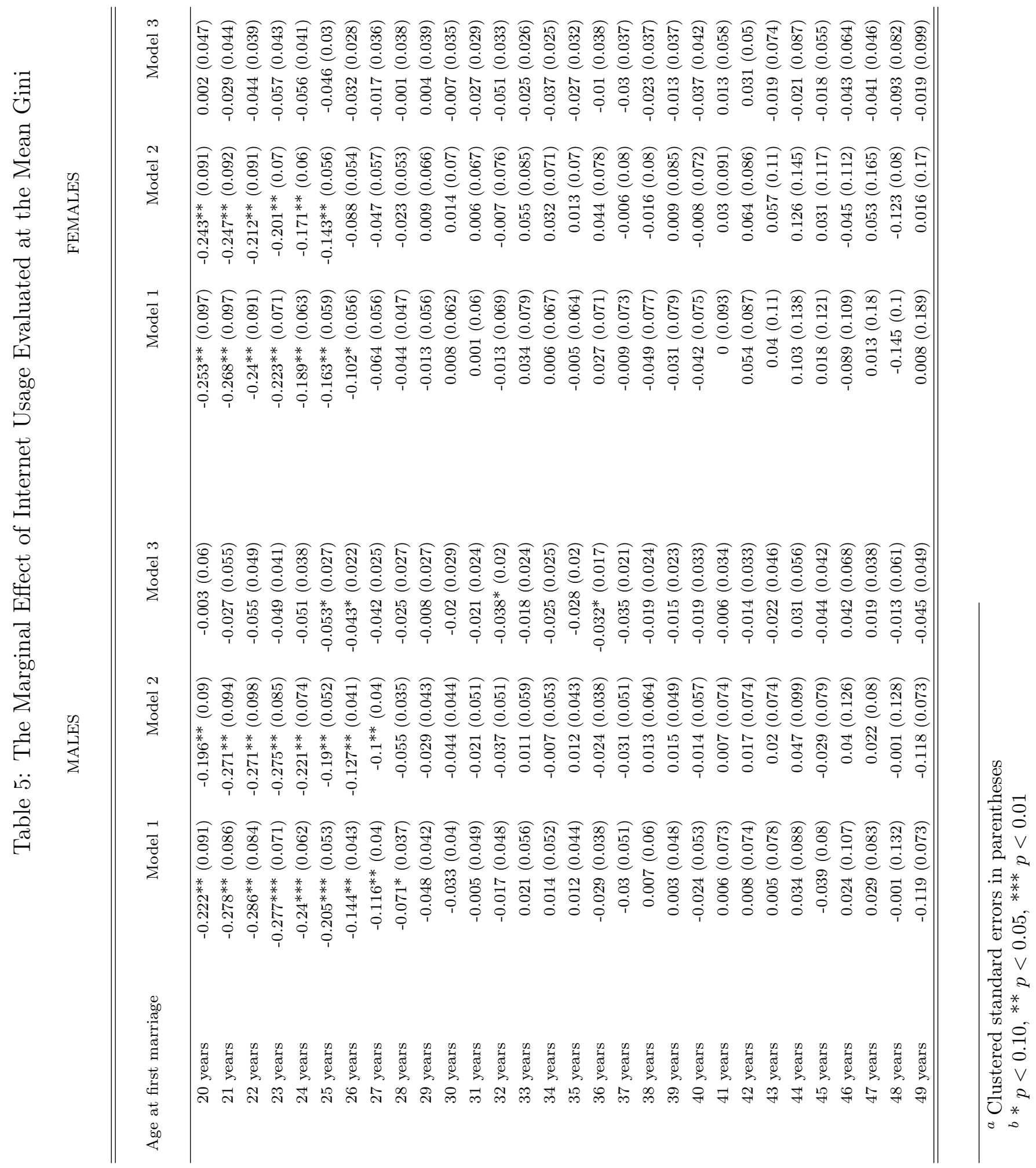




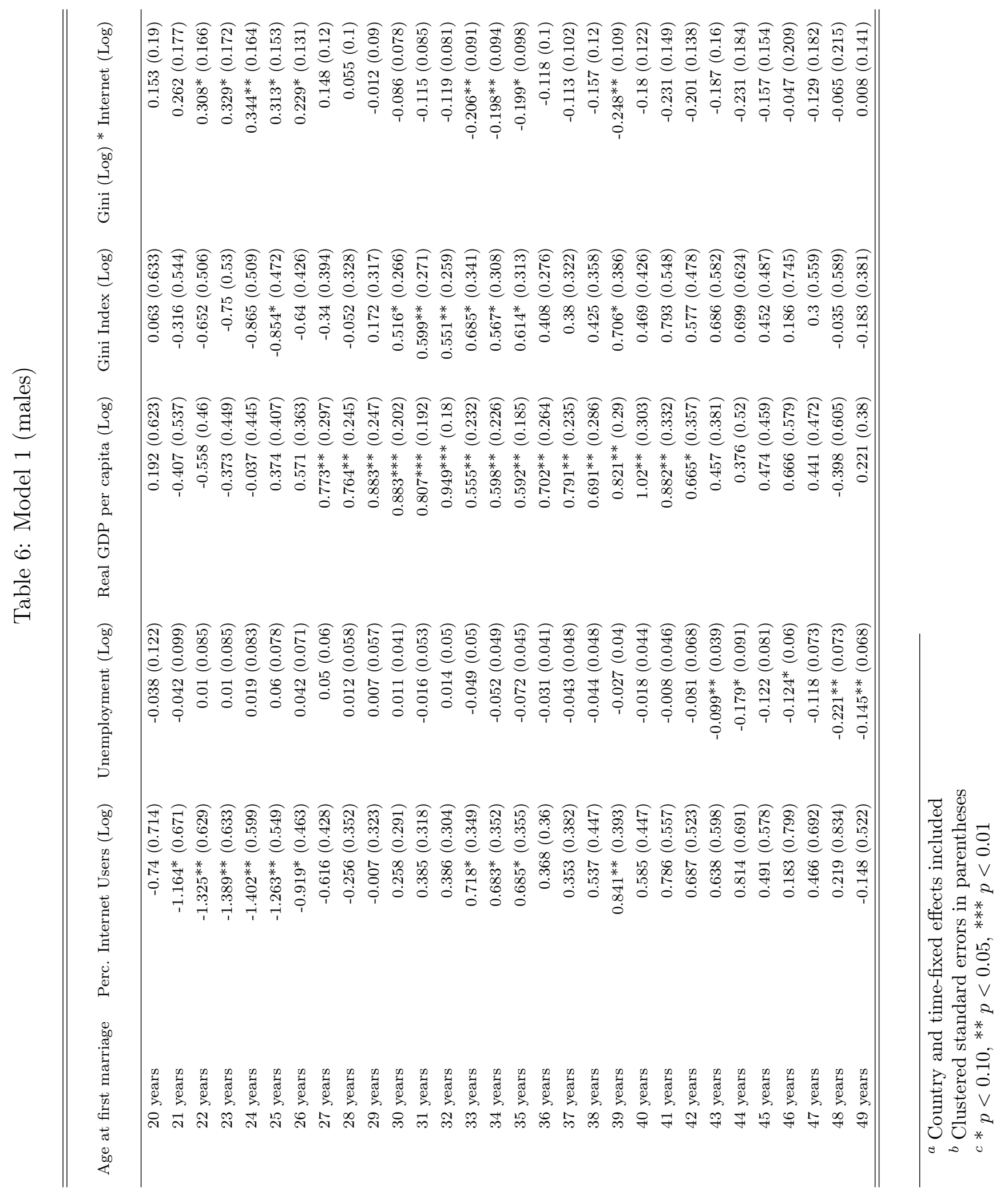



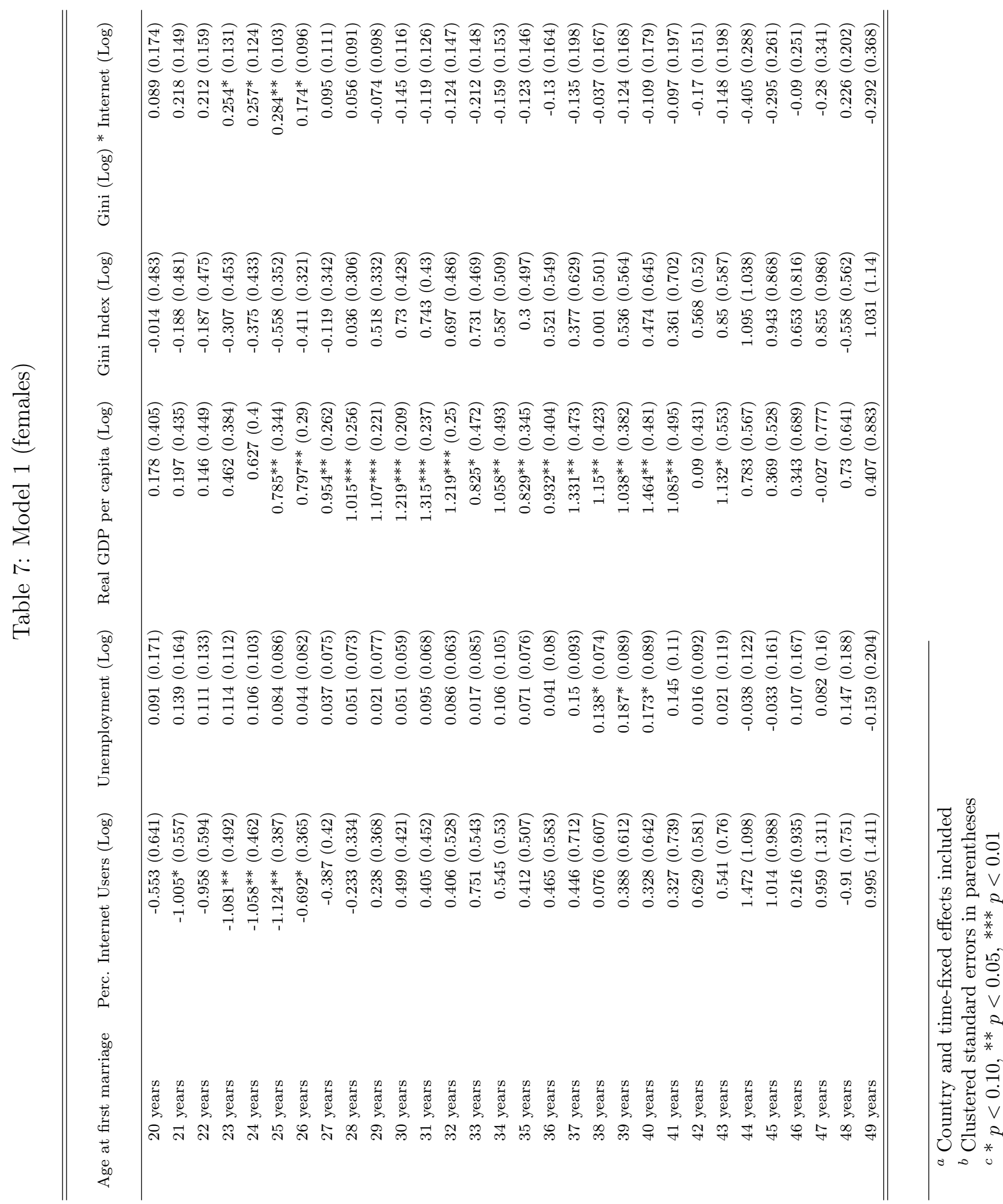


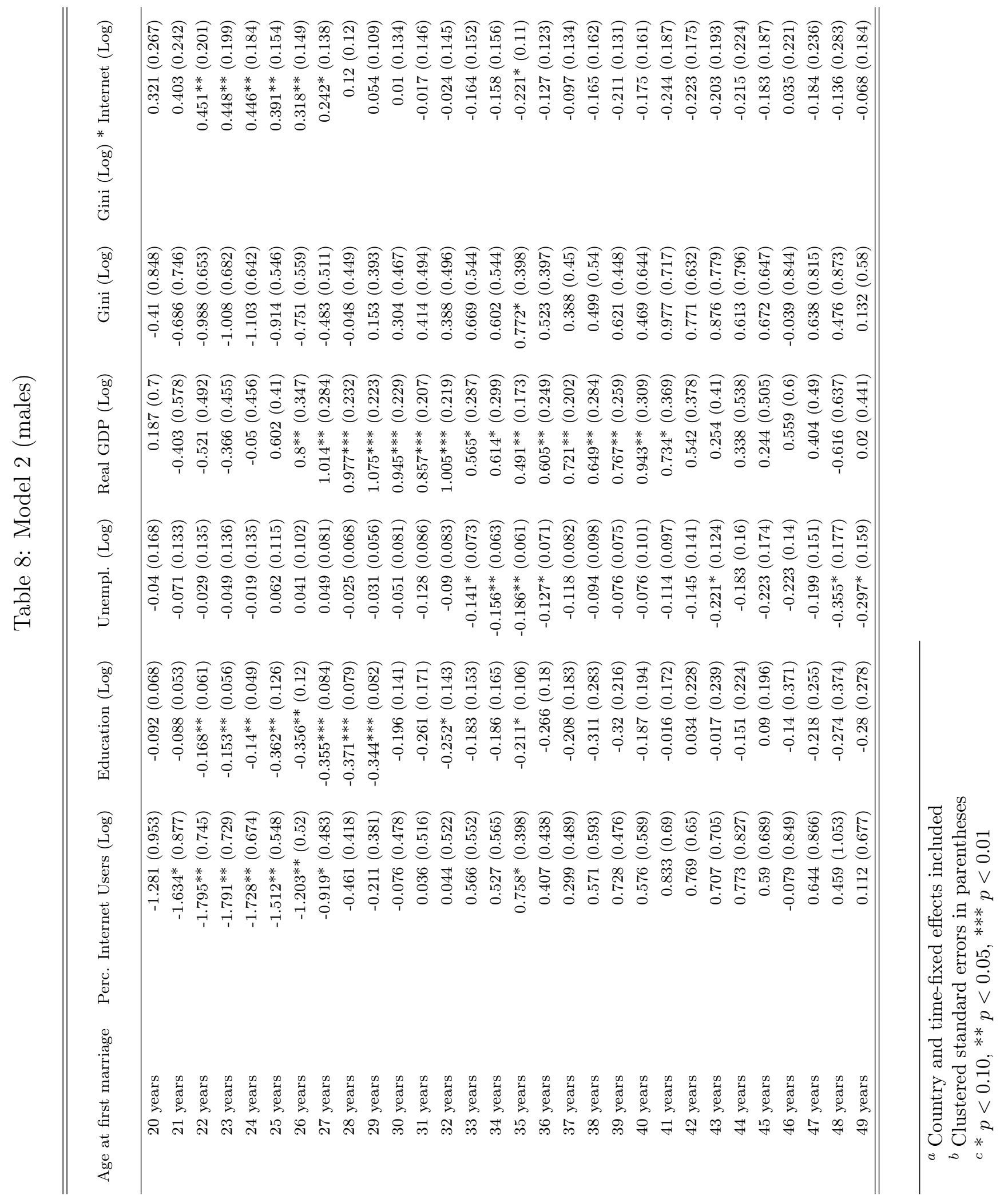



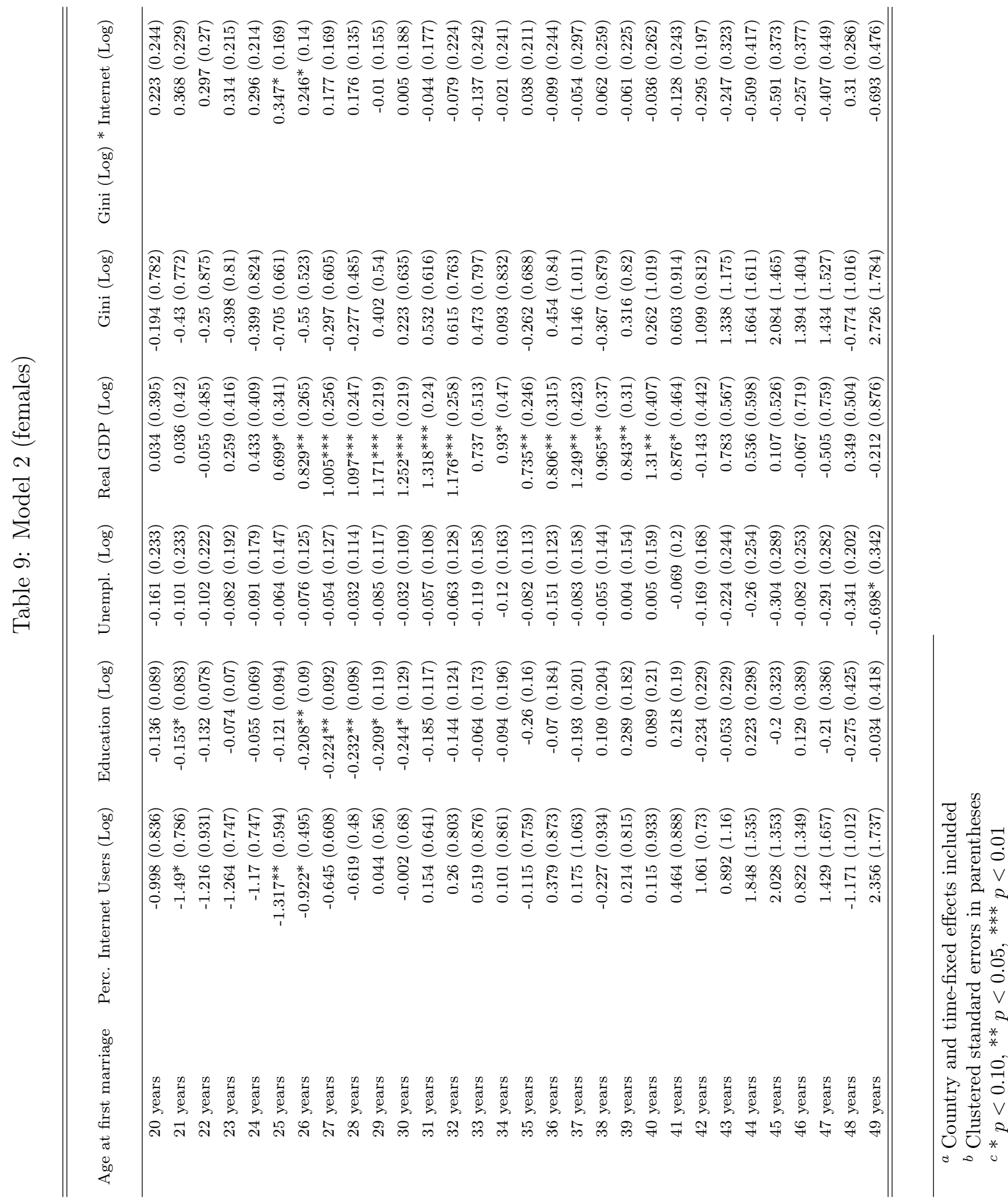


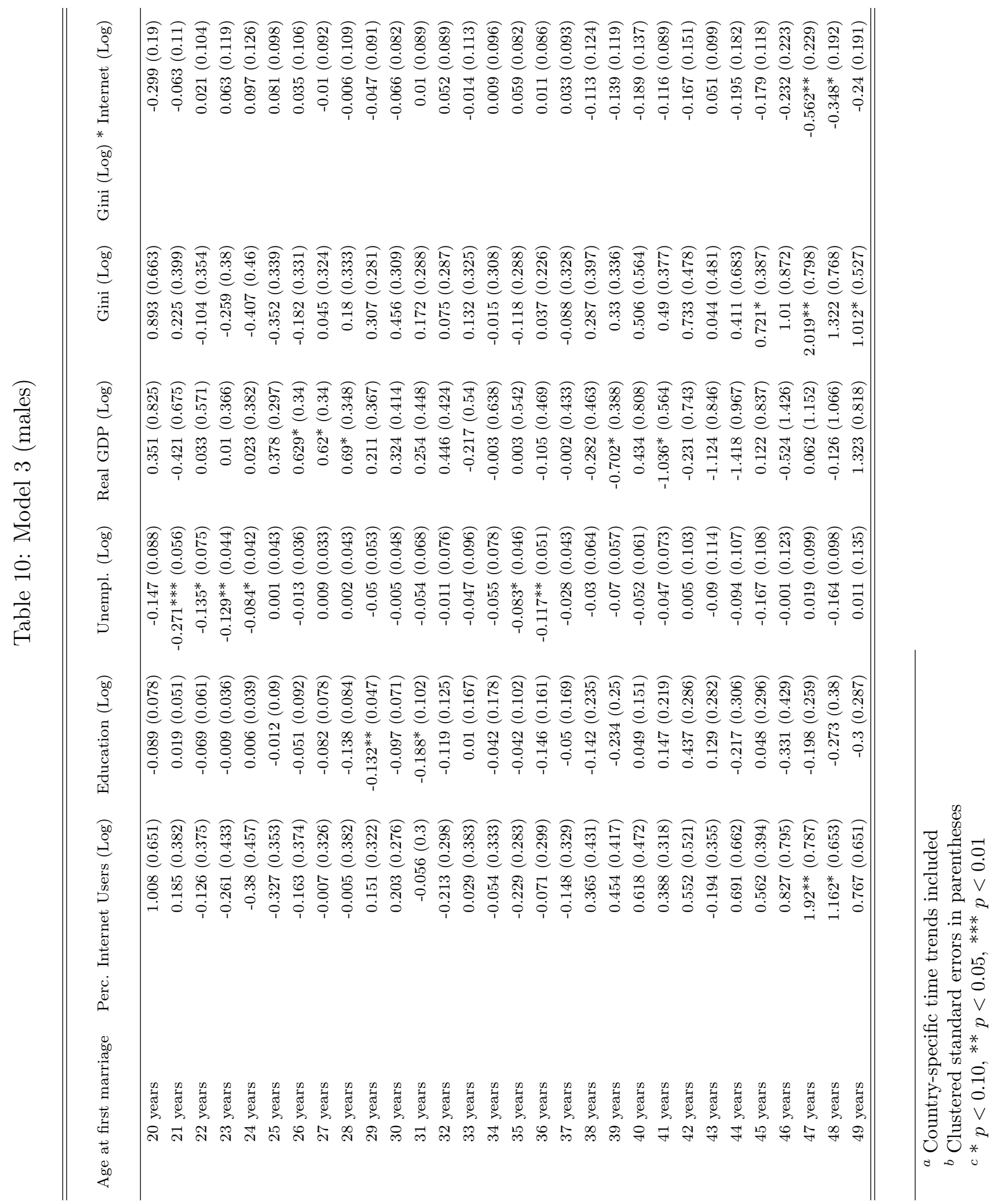




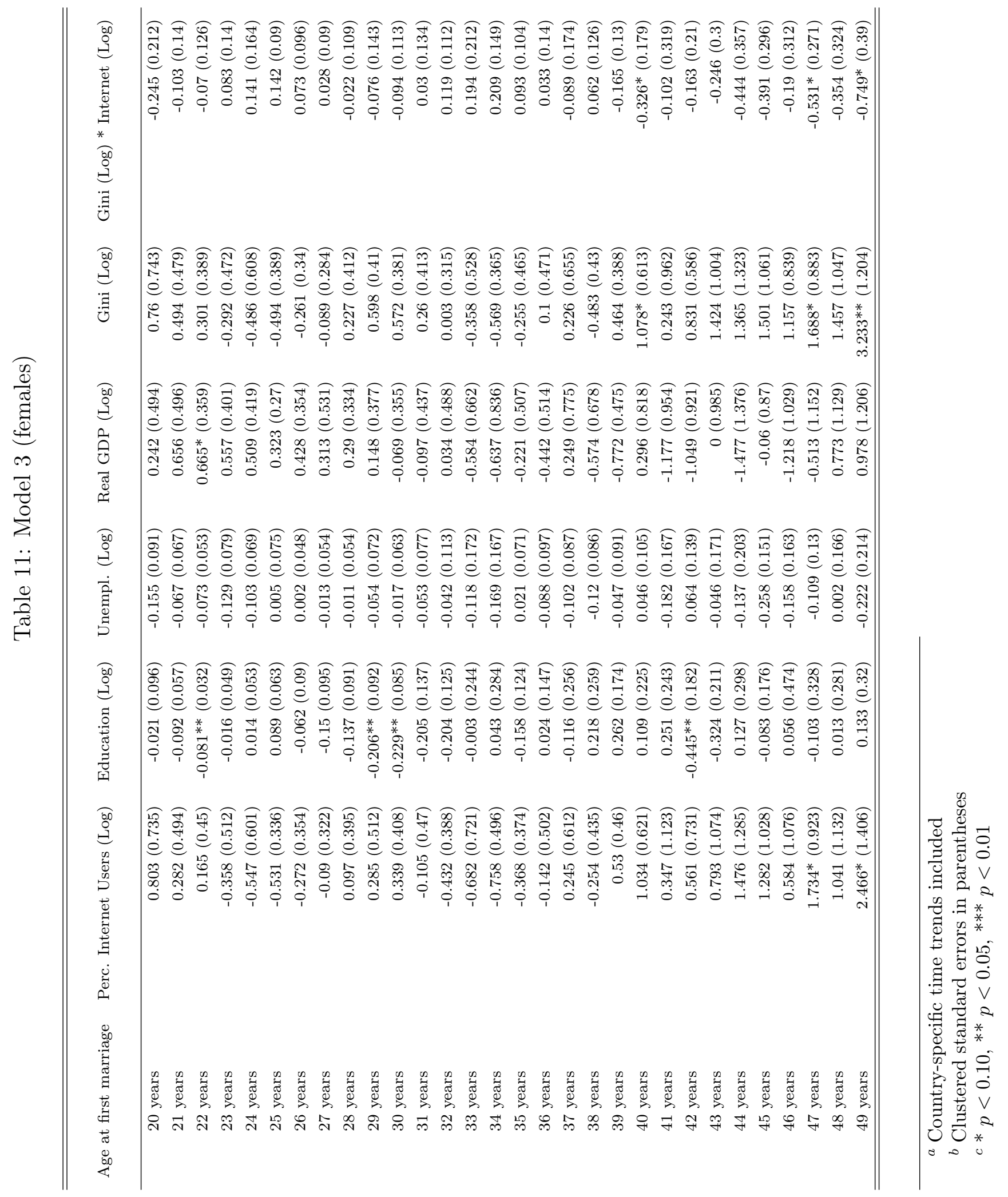




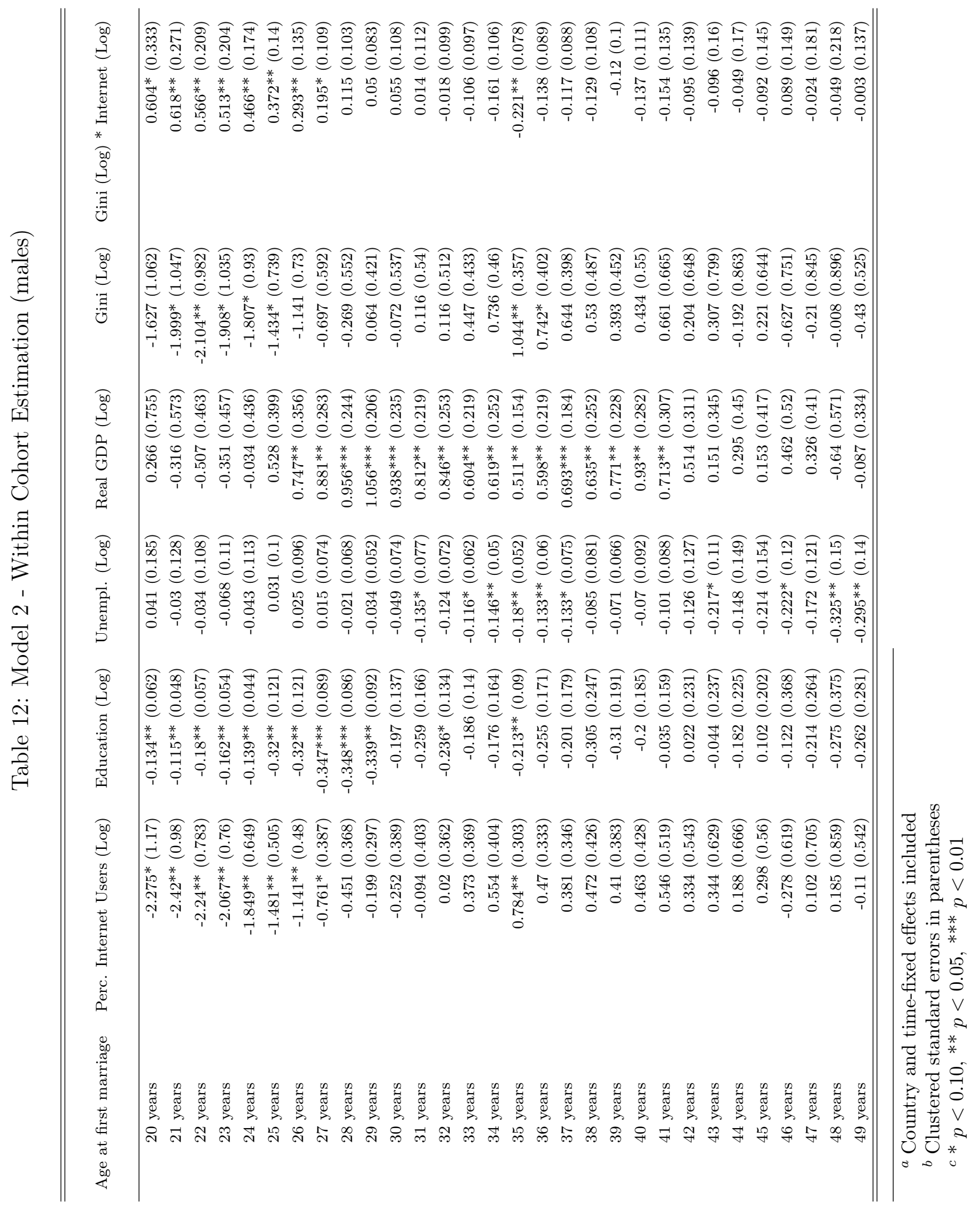




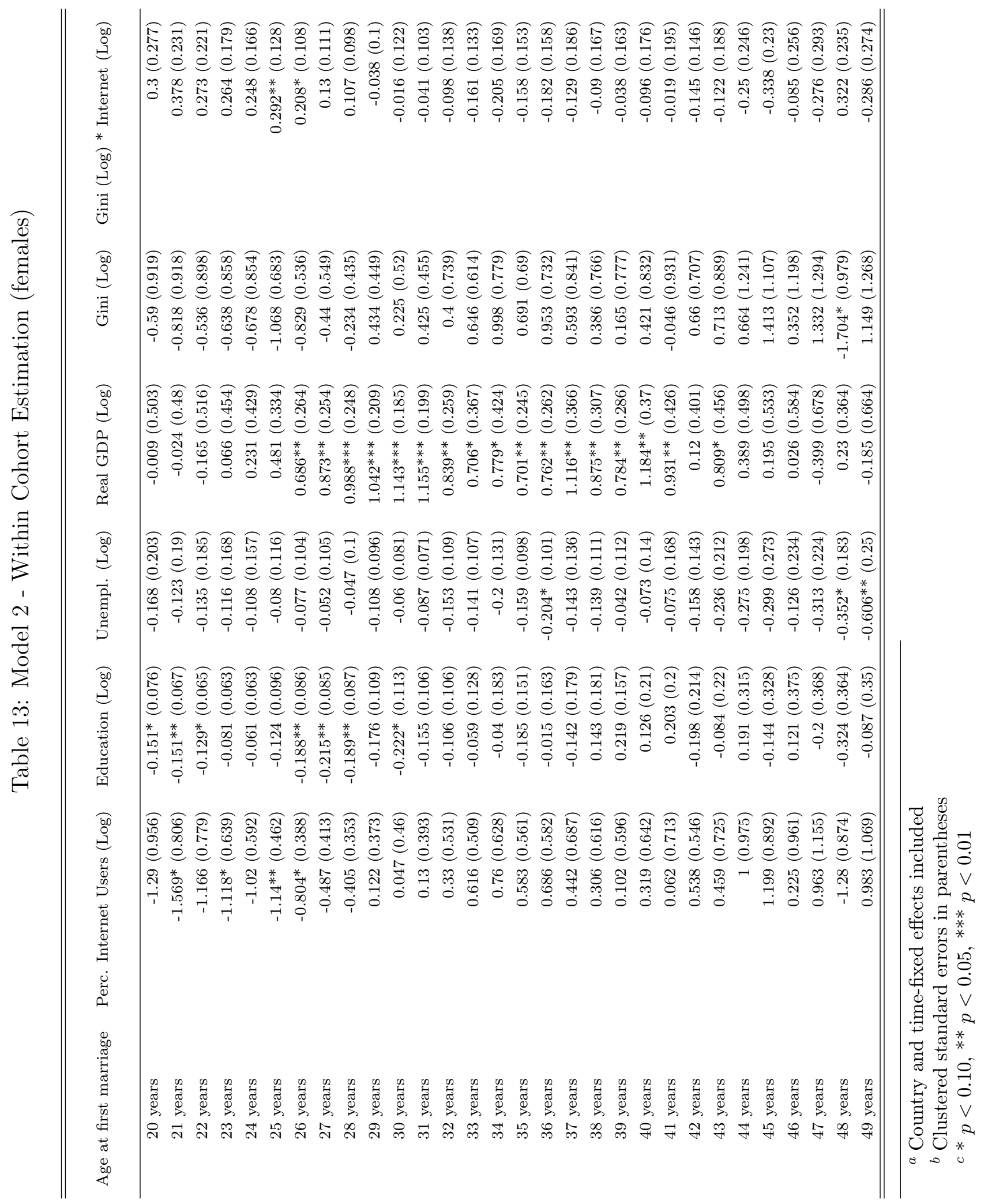


Table 14: The Marginal Effect of Internet Usage Evaluated at the Mean Gini for Model 2 Using Within Cohort Estimation

\begin{tabular}{|c|c|c|}
\hline Age at first marriage & Males & Females \\
\hline 20 years & $-0.234^{* *}(0.087)$ & $-0.275^{* *}(0.092)$ \\
\hline 21 years & $-0.332^{* *}(0.095)$ & $-0.291^{* *}(0.094)$ \\
\hline 22 years & $-0.326^{* *}(0.1)$ & $-0.245^{* *}(0.092)$ \\
\hline 23 years & $-0.332^{* *}(0.091)$ & $-0.224 * *(0.071)$ \\
\hline 24 years & $-0.273^{* *}(0.078)$ & $-0.181^{* *}(0.06)$ \\
\hline 25 years & $-0.225^{* * *}(0.05)$ & $-0.154^{* *}(0.059)$ \\
\hline 26 years & $-0.149^{* *}(0.051)$ & $-0.101^{*}(0.058)$ \\
\hline 27 years & $-0.103 *(0.05)$ & $-0.047(0.067)$ \\
\hline 28 years & $-0.063(0.047)$ & $-0.045(0.057)$ \\
\hline 29 years & $-0.032(0.054)$ & $-0.005(0.069)$ \\
\hline 30 years & $-0.065(0.05)$ & $-0.009(0.083)$ \\
\hline 31 years & $-0.046(0.057)$ & $-0.01(0.076)$ \\
\hline 32 years & $-0.041(0.058)$ & $-0.002(0.096)$ \\
\hline 33 years & $0.013(0.07)$ & $0.071(0.1)$ \\
\hline 34 years & $0.011(0.065)$ & $0.068(0.095)$ \\
\hline 35 years & $0.038(0.055)$ & $0.047(0.092)$ \\
\hline 36 years & $0.003(0.05)$ & $0.071(0.09)$ \\
\hline 37 years & $-0.013(0.065)$ & $0.007(0.092)$ \\
\hline 38 years & $0.036(0.085)$ & $0.002(0.092)$ \\
\hline 39 years & $0.003(0.064)$ & $-0.025(0.091)$ \\
\hline 40 years & $0(0.072)$ & $-0.006(0.097)$ \\
\hline 41 years & $0.026(0.086)$ & $-0.003(0.098)$ \\
\hline 42 years & $0.013(0.093)$ & $0.049(0.096)$ \\
\hline 43 years & $0.018(0.106)$ & $0.047(0.128)$ \\
\hline 44 years & $0.021(0.118)$ & $0.154(0.176)$ \\
\hline 45 years & $-0.015(0.097)$ & $0.057(0.154)$ \\
\hline 46 years & $0.024(0.142)$ & $-0.064(0.137)$ \\
\hline 47 years & $0.021(0.116)$ & $0.032(0.199)$ \\
\hline 48 years & $0.021(0.16)$ & $-0.192^{*}(0.107)$ \\
\hline 49 years & $-0.121(0.106)$ & $0.017(0.187)$ \\
\hline
\end{tabular}




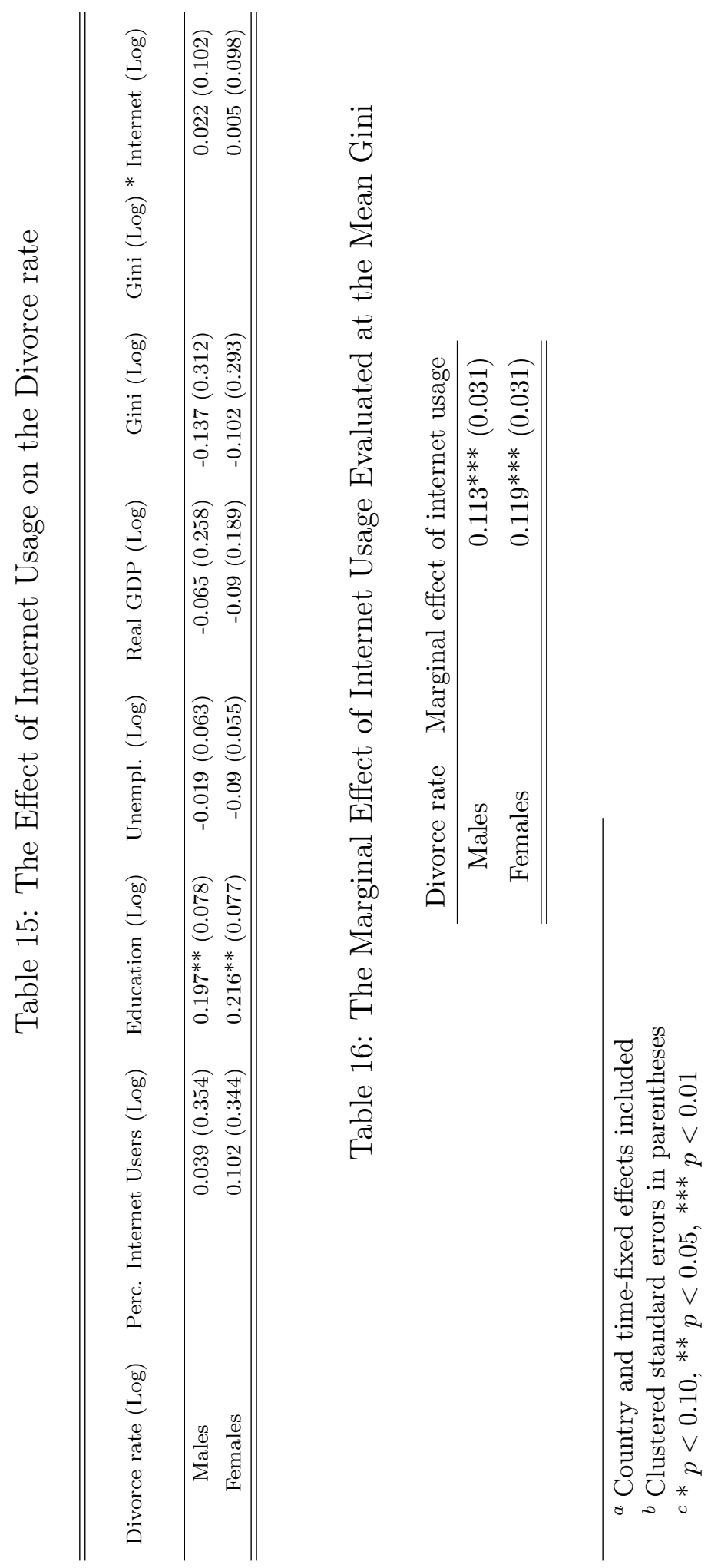




\section{Working Paper Series}

ISSN 1211-3298

Registration No. (Ministry of Culture): E 19443

Individual researchers, as well as the on-line and printed versions of the CERGE-EI Working Papers (including their dissemination) were supported from the European Structural Fund (within the Operational Programme Prague Adaptability), the budget of the City of Prague, the Czech Republic's state budget and the following institutional grants:

- Center of Advanced Political Economy Research [Centrum pro pokročilá politickoekonomická studia], No. LC542, (2005-2011);

- Economic Aspects of EU and EMU Entry [Ekonomické aspekty vstupu do Evropské unie a Evropské měnové unie], No. AVOZ70850503, (2005-2011);

- Economic Impact of European Integration on the Czech Republic [Ekonomické dopady evropské integrace na ČR], No. MSM0021620846, (2005-2011);

Specific research support and/or other grants the researchers/publications benefited from are acknowledged at the beginning of the Paper.

(c) Mário Vozár, 2011

All rights reserved. No part of this publication may be reproduced, stored in a retrieval system or transmitted in any form or by any means, electronic, mechanical or photocopying, recording, or otherwise without the prior permission of the publisher.

Published by

Charles University in Prague, Center for Economic Research and Graduate Education (CERGE) and

Economics Institute ASCR, v. v. i. (EI)

CERGE-EI, Politických vězňů 7, 11121 Prague 1, tel.: +420 224005 153, Czech Republic.

Printed by CERGE-EI, Prague

Subscription: CERGE-EI homepage: http://www.cerge-ei.cz

Phone: + 420224005153

Email: office@cerge-ei.cz

Web: http://www.cerge-ei.cz

Editor: Michal Kejak

Editorial board: Jan Kmenta, Randall Filer, Petr Zemčík

The paper is available online at http://www.cerge-ei.cz/publications/working_papers/.

ISBN 978-80-7343-247-8 (Univerzita Karlova. Centrum pro ekonomický výzkum a doktorské studium)

ISBN 978-80-7344-239-2 (Národohospodářský ústav AV ČR, v. v. i.) 
CERGE-EI

P.O.BOX 882

Politických vězňů 7

11121 Praha 1

Czech Republic http://www.cerge-ei.cz 